\title{
Caroline Chisholm: public pedagogy personified
}

Flossie Peitsch

\section{Victoria University}

\begin{abstract}
This article relays stories of Caroline Chisholm's radical intervention into life on Australia's Victorian Goldfields. The author argues that Chisholm's role in the cultural transformations of the period establish her as a public pedagogical pioneer influencing Australia to this day. Through her tireless engagement with the broader community, Chisholm is seen as an inspiration for public service, while inviting discussion on its challenges. The author connects this history with her own experiences as a female artist and community-based art projects that explore Chisholm's legacy.
\end{abstract}

\section{Keywords}

Caroline Chisholm; Australian history; community art; visual art; women 
Within the field of public pedagogies, this is a time when 'looking ahead' can also mean 'looking back'. At recent conferences and events we have reflected on public pedagogical approaches from history and considered what role they play in the present. Once considered, these past strategies might well influence future practice. This notion is the perfect backdrop to reflect on the historical figure of Caroline Chisholm $(1808-1877)$ and her effective life of non-sectarian, non-government, non-institutional humanitarian service in the mid-1800s. Importantly, claiming her passions but not her noteworthy reputation, Chisholm is also a figure with whom I feel a personal affinity.

This article relays stories of Chisholm's radical intervention into life on Australia's Victorian Goldfields. Her role in the resultant cultural transformations of the period establish Chisholm as a public pedagogical pioneer influencing Australia to this day. Through her tireless engagement with the broader community, Chisholm personifies an exemplar of work in this field, while inviting discussion on its challenges. Highlighting the categories identified by research in public pedagogies (Sandlin, et al., 2001), this text aligns Chisholm's creative social intervention with contemporary theory and practice.

\section{Caroline Chisholm: Looking Ahead}

It is rare in contemporary society to find a figure who embraces the perspective and celebrates the hope of the human community (Henry, 2004). Digging into the past, I found such a person in Caroline Chisholm, a colonial immigrant to Australia from England: 'Caroline was a woman looking for a home' (Stevens-Chambers, 2005, p. 1). This sentence connects to my own experience and is perhaps my strongest connection with Chisholm. Even while identifying with the sense of displacement, to me, she contradictorily exemplifies community-in spirituality and connectedness.

For a time, the Australian government recognised community-minded Chisholm for her vast contribution to the welfare of thousands of transported convicts and immigrants to Australia's harsh shores, symbolised by Chisholm's portrait appearing on the Australian five dollar note until 1992. Like others, I had passed along her visage for nearly twenty years without giving her work any special thought.

Chisholm was an advocate for immigrant's rights, especially for women, and families. This accomplishment was driven by Chisholm's Christian spirituality and great desire to help families and new immigrants. It was her belief that the best influences on the developing country were family life (Bogle 1993) (Stevens-Chambers 2004) (Hoban 1974) (Knights 1992). While being a woman of her time, Chisholm was not hampered by such. She used every opportunity to value the knowledge of the people of her day-Indigenous, European, Chinese, and locals-working outside of, but alongside, the formal public institutions of the region. I would argue that Chisholm did not accept 'culture' passively but instead saw it closer to its understanding by cultural theorist Stuart Hall as 'a critical site of social action and intervention, where power relations are both established and potentially unsettled' (Procter 2004, p. 24). Chisholm was a firm believer in empowering people to create change for themselves and their community, and succeeded through great personal sacrifice, political involvement, integrity, intelligence, organization and the pragmatic application of practical ideas (Hoban 1974).

Caroline Chisholm's story is integral to the development of the gold rush affected areas of Victoria from 1855-1865. On every public occasion, she spoke eloquently and with authority:

'May the frightful and sorrowful position we are in induce us all with one spirit to co-operate in bringing about a more credible state of things. Let us cast aside all party 
feeling or class interest. Let us retrench, economize, and abandon the idea that getting further into debt will clear us of our difficulties.

Let us be wise in time and give to our people a fair scope for their activity, a wider and more wholesome range for their energies, and we shall soon become a happy, contented people.

We have become a nation of consumers, instead of producers. We must alter our system if we wish to recover our character.' (Swann 1925, p. 56-57)

This powerful speech is not-as it may sound-the pious pontification of a contemporary politician who wants only to rouse votes to ensure continuing office. On the contrary, it is the heartfelt and insightful pleading of arguably Australia's greatest humanitarian in the nineteenth century. It is part of an impassioned hour-long speech at a public meeting in Melbourne reporting on her finds from visiting the diggings. As a personal social practice in a social setting of Chisholm's own making, it can also be seen as a form of public pedagogy (Giroux, 2004).

Figure 1: Chisholm's Homes Project Banner, incorporating the design of the Australian five dollar note

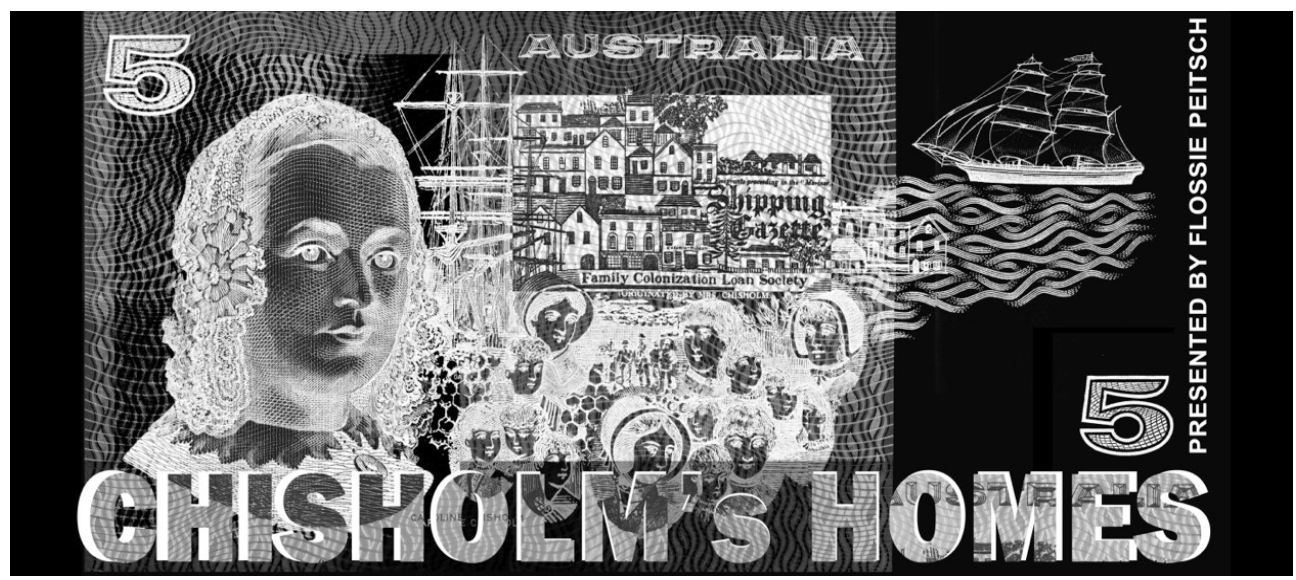

\section{Chisholm's Homes}

In response to my research on Caroline Chisholm, in 2005 I developed Chisholm's Homes, a project celebrating the 150th anniversary of Chisholm's Shelter Sheds. Instigated and designed by Chisholm, the 10 shelter sheds or colloquially, 'Shakedowns', safely harboured those walking to and from the Goldfields from November 1855-1865 (Peitsch, 2006). My intention was to use the arts to create an increased community spirit, to gain higher regard for service and respect for others as inspired by the example of Chisholm and her dedicated local involvement with immigrants. As part of the project, public workshops produced sculpture, paintings and new media productions, and involved over 1,000 people from many locations. In addition to the historical interest, the project generated inquiry into the everyday environment of spirituality, changing family location, relationships, and the emergence of selfhood in today's community (Peitsch, 2004).

I had often felt discouraged working on my $\mathrm{PhD}$, as if I was working against impossible odds. Then I had often wished I could talk to someone else doing fulltime research who had a wide-ranging topic; must raise funds to realise their projects; had a restrictive completion date with no administrative help; was raising six children, four of whom were teenagers; had no extended family support, or domestic help; had limited finances, energy, 
time; and whose husband's work required his frequent absences. Not surprisingly, no one came to mind easily (Peitsch, 2008).

Unexpectedly, I read about Caroline Chisholm in a brief newspaper article about her and her work and history in the Goldfields of Victoria (Murphy, 2004). I felt like I recognised a familiar passion, only much more than I could have imagined. My complicated lifestyle and profession seemed frivolous when compared to the arduous life of this woman of high spiritual conviction and practical action. Chisholm achieved astounding social results (Hoban, 1974). In July 1854, Chisholm arrived in Port Philip to large adoring crowds. She was already a person with a reputation for offering practical means for improving the plight of the immigrant during her previous efforts in New South Wales and in England. During her lifetime (1808-1877) Chisholm had become famous and has been described as recognised on the street in England equally to Queen Victoria (Hoban, 1974) (Swann, 1925).

Almost immediately on her arrival in Victoria, Chisholm heard stories from unfortunate women with needy children and no means of support, who reported that their poor husbands struggling in the goldfields had, sadly, broken their legs, could not work and were unable to send any money (Swann, 1925). Chisholm thought this situation needed to be substantiated so hitched up a team of horses to a wagon and set out to find these pitiable creatures. Not surprisingly to her, the men had not been bedridden at all but were spending the profits of their diggings. She deduced that by creating safe travel for the women and their children to join their husbands, the pressing social issues of the time and place could be addressed and she was to be proved right (Bogle, 1993).

Chisholm observed major difficulties for life in the goldfields during her self-initiated tour. The mode of life for the miners, or 'diggers' as they were known, was very rough. Many lived in tents or huts with water and food scarcity, or they tramped along carrying humble swags. Travel was dangerous or costly (Swann, 1925). Needless to say, there were almost no women in the area. This Chisholm alluded to by saying, 'Many of the lodging-houses were kept by men, and you know very well that men are bad hands at making a pudding' (Swann, 1925, p. 53). Vegetables, fruit and other foodstuffs were rare.

At this time, there was an impossibility of obtaining land for growing anything. Diggers were prohibited by the government from gaining small parcels of land in order to build a home or till the soil. Additionally, they were expected to obtain licences to mine (Swann, 1925). These papers were to be on their persons at all times. Dire consequences were applied by policemen if the papers were not found. Miners did not mind the licences but objected to the cruel public punishment inflicted. It was a time when bushrangers were not caught, but the miners were. Great unrest developed. The government was deaf to the cries for justice and daily need.

Never dependent on government support, Chisholm's attitude of 'not asking the government to do for us-but rather asking what we could do for ourselves' (Swann, 1925, p. 54) applied to her scheme for improvement. Chisholm planned to raise money to supply accommodation in regional Victoria. First she sold tickets to subscribers who were entitled to nights' lodgings equal to the amount invested (Swann, 1925). Then in 1855, Chisholm cajoled the government to build, in one year, 10 Shakedowns or Shelter Sheds between Melbourne and the Victorian Goldfields.

To mobilise a government for this enormous production in one calendar year was truly a feat. These sheds were built one days' walk apart stretching from Essendon to Keilor, then Robertson to The Gap, then Gisborne to Woodend, Carlsruhe, Malmsbury and finally Elphinstone. All travellers slept cheaply and safely side by side-Indigenous, 
Chinese, new immigrants, and locals. A creative solution to a far-reaching problem, it is fully credited to one proactive and inspired Victorian female.

This creative solution addressed issues of spirituality, family and home. As a result I feel a great personal affinity with Chisholm. By happenstance many of her life choices and directions align with my own. Like myself, she was the youngest of a large family with doting older sisters. She was baptized into the family faith as a baby and worshipped regularly developing a strong spirituality and sense of justice. She had a stable family life and happy confident childhood. Her play was involved, adventurous, taking her to faraway imaginative places and sometimes getting her into trouble. Her family often took in strangers in need and shared what they had. She amazed her family with her odd questions about life and dismayed them with her lack of interest in the local boys. A 'foreigner' caught her eye and she married at just over twenty. Work immediately took them from home and so she left all familiar community. Some family members were alienated by the change of religion and culture she experienced (Hoban, 1974). At this time she took drawing lessons showing considerable artistic aptitude (Hoban, 1974). In all these I have found parallels with my own experiences (Peitsch, 2008).

Her husband, Archibald, was away from home for extended periods. He encouraged her in her special field of work while he was gone (Bogle, 1993) and had full confidence in her abilities. Nonetheless, many would understand the daily strains of being a single parent while trying to meet outside commitments. I certainly do. The time wears long and wearisome-bringing its own stress. Earlier, Chisholm had lost her first pregnancy, possibly causing a depression and augmenting loneliness (Stevens-Chambers, 2004). Despite further losses, ill babies and her own health concerns following birth, she mothered six children. She had a great heart for her family and later, when others questioned her ability to raise her own children while seeing to her vocation, took criticism of this situation hard. I have experienced this too.

Being a mother and an intelligent and educated woman living in England's Victorian period was problematic for Chisholm in many ways. In the critical world of her day, she was said to be using a 'masculine brain' (Hoban, 1974) (Stevens-Chambers, 2004). She was very organised and concerned with good planning for successful projects, even at great personal cost. She did not accept that the world must continue as it is. She respected and spoke for all people's rights, including the 'original holders of this soil' (Bogle, 1993). Chisholm was non-sectarian in her work, not even accepting government payments at times to ensure her objective viewpoint. She used her intelligence to alter society's views for the welfare of all.

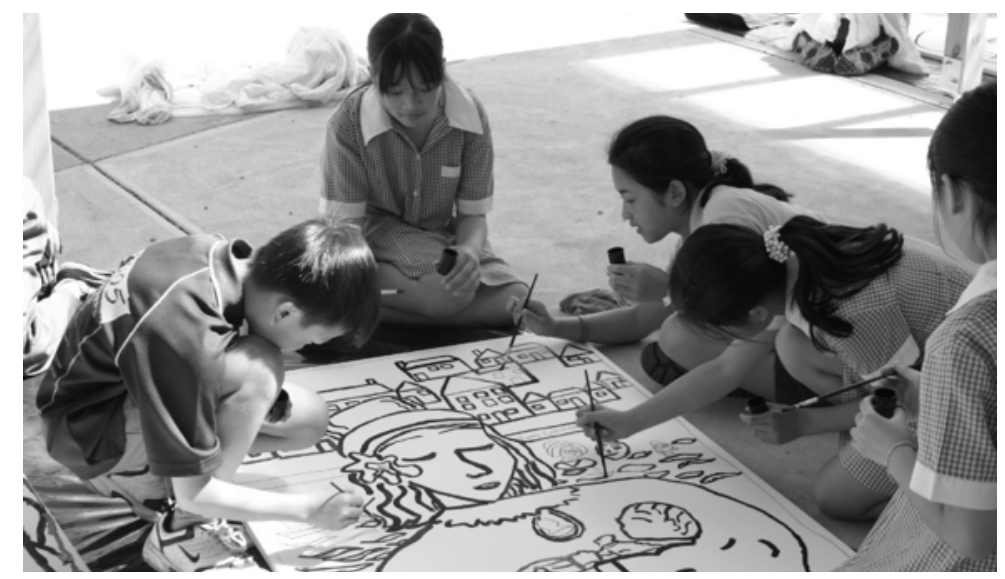

Figures 2: Samples of Chisholm's Homes Projects 

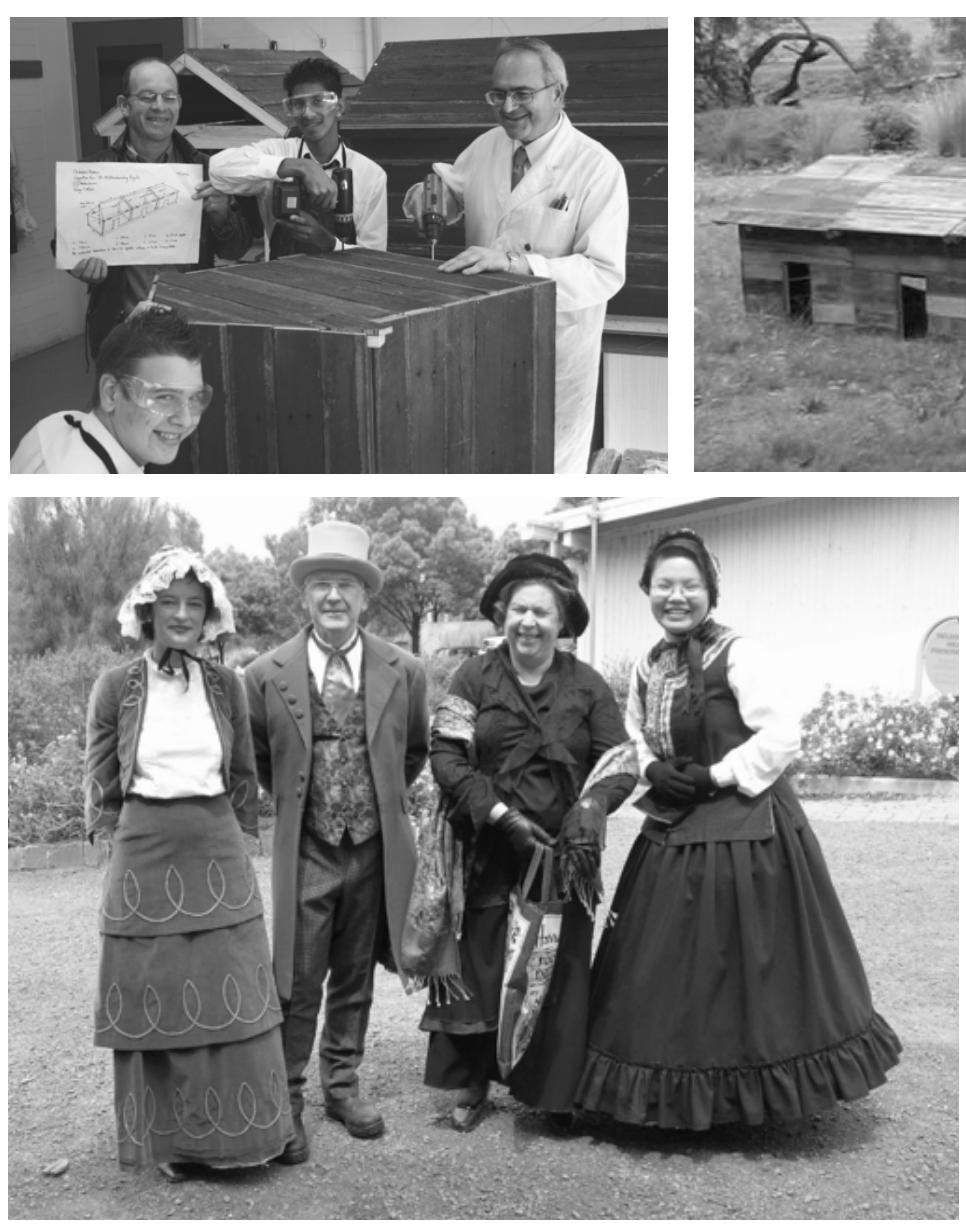

Figures 3 \& 4: Samples of Chisholm's Homes Projects (top)

Figure 5: Chisholm's Homes Participants in period costume (above) Figure 6: Peitsch dressed as Chisholm to deliver a talk on her achievements at a Lions' Club Presentation (above right)

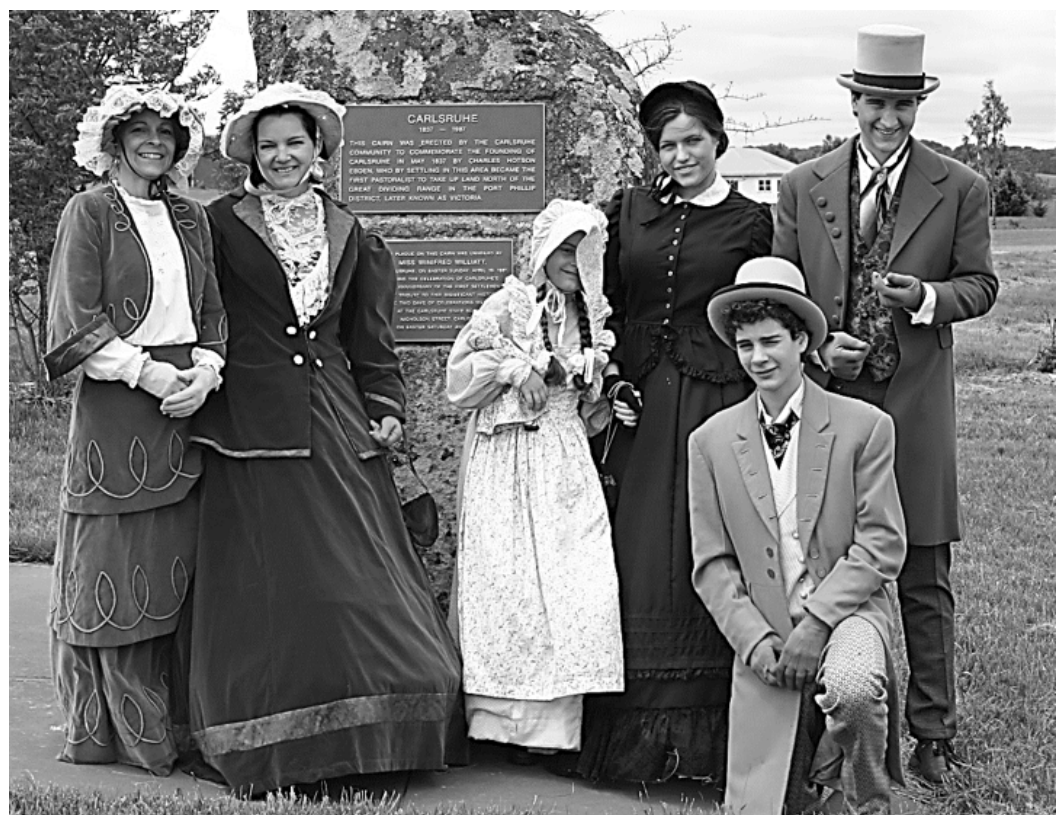

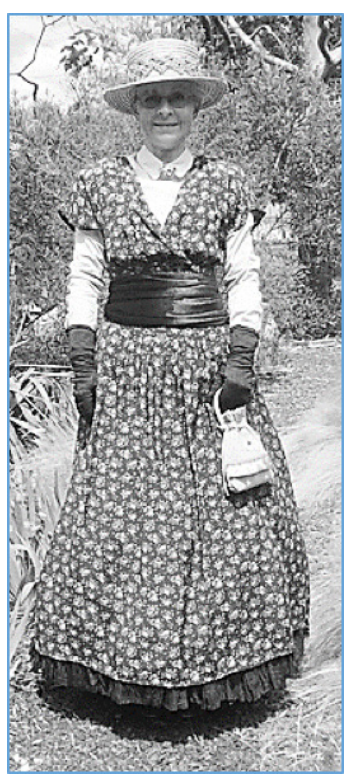

Con SALE:AT

Chisholm, Brothers.

. morosisas axp getrail

WINE, SPIRTT, PROVISION,

DRAPERY AND ARONHONGRAT STORE

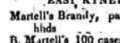

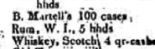

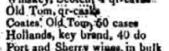

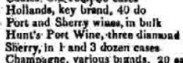

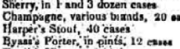

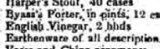

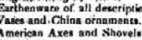

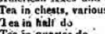

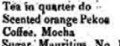

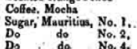

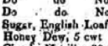

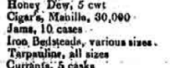

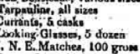

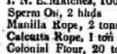

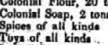
Pandiers, 20 o.

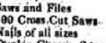

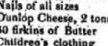

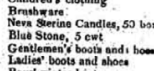

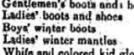
While and on Ironmoogery
CHISHOLAT, BROTHERs.

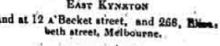

Figure $7 \&$ 8: A group dressed in period costume in 2005, to celebrate the 150th year since the establishment of the Carlsruhe Shelter (above) and advertising material for the Chisholm's Kyneton store 


\section{Caroline Chisholm: Paragon In Petticoats}

A woman living in a male-controlled world, Caroline Chisholm was, indeed, a paragon in petticoats in patriarchal times, though this would not have been a self-prescribed label. Chisholm saw herself as an ordinary person-guided by Providence-fulfilling what was to be her vocation in life, merely, that of changing the world as she knew it (Kiddle, 1950). An unlikely job for any person-let alone a woman in the Victorian period. For Chisholm, changing the world was all about investing herself in community.

An early British immigrant yet a local-having chosen to live in 'her beautiful Kyneton' for a period and there run a supply store from 1855-1861 (Stevens-Chambers, 2005). While a resident in Kyneton, Chisholm was a woman for all times. During her lifetime, she was a standalone humanitarian in the wily goldfields of Victorian Australia, her name becoming synonymous with compassion, respect and rectitude (Stevens-Chambers, 2004).

It is an appropriate time to celebrate Chisholm's achievements through a renewed evaluation of her contribution and the continuing relevance of her work in contemporary society. This text seeks further to align the life of the historical inspiration Caroline Chisholm-comparing issues she faced as an peripatetic colonial woman-with Australia's current life and citizenship. This may serve as a vehicle to develop an increased community awareness and good spirit in regards to service and respect for women and families and by doing so, inspire practical steps for improvement.

Chisholm made significant contributions to the welfare of women and children, the status of families, the reform of passenger shipping, the availability of low interest loans (Szoke, 2008). Beginning with the pressing issues facing young women in the colony she soon became an advocate of immigration as a solution to both the poverty and overcrowding in England and the need for labour in the developing colony (Bogle, 1993). Chisholm had the extraordinary ability to understand the social problems of her day and conceive practical solutions. One such amazing accomplishment was producing her original design for a purpose-built ship to transport free settlers and newly-freed convicts' families to Australia. Caroline was inspired to improve the ships on this route after her own personally disastrous voyage returning to England in what she referred to as little more than intolerable cargo transport.

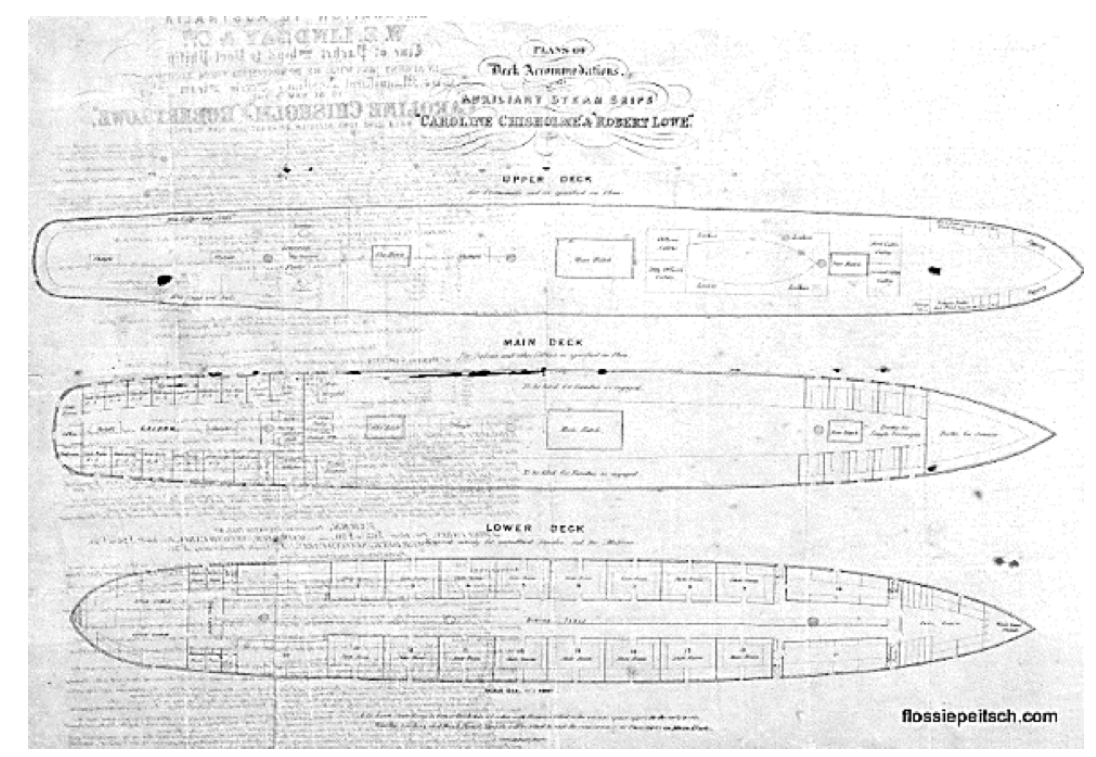

Figure 9: Chisholm's original drawing for the ship The Caroline Chisholm 
The drawing is in the possession of her direct descendants who live in Sydney. It seems obvious that the Australian Government should be making efforts to acquire this drawing and the other Chisholm artefacts-a wedding clock, a personally autographed Bible, a book of Memoirs, her design of the 'Caroline Chisholm' tall ship, her portrait bust from the Pope, and a small plate entitled 'The Emmigrant's Friend'-as significant to Australia's history, awaiting public attention and viewing. However, to date no indication of this procurement is forthcoming.

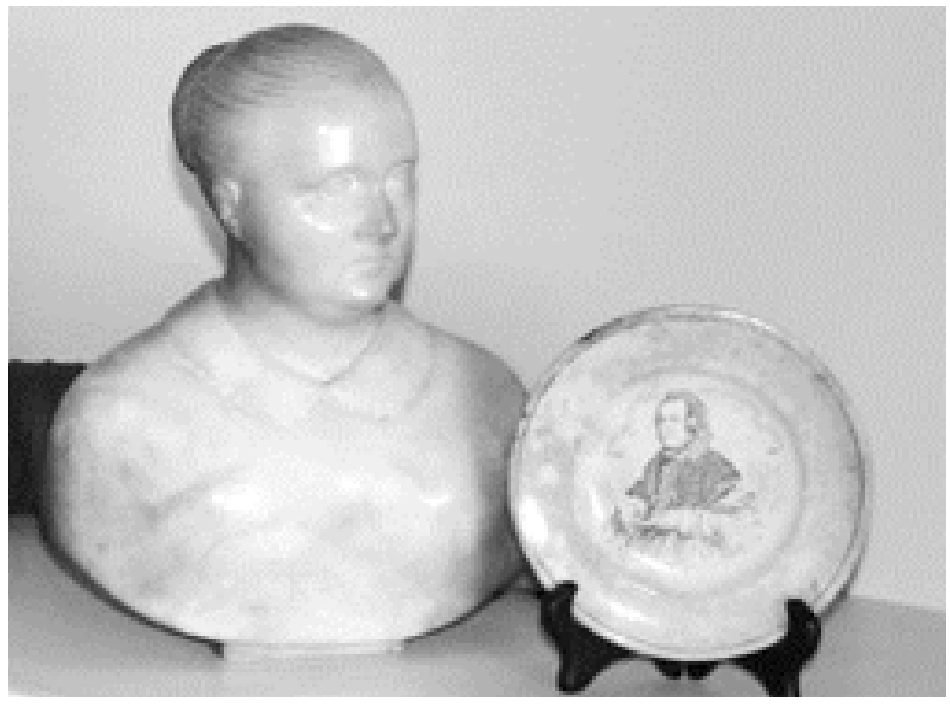

Figure 10: Chisholm's portrait bust from the Pope, and a small plate entitled 'The Emmigrant's Friend'

The government in many ways turned a blind eye to her truly heroic achievements even in her lifetime. Her energy and enthusiasm has a spiritual source, but she was free from sectarianism in implementing her vision. Raised an active Protestant and then rebadged at marriage as a Catholic, Chisholm was not naïve to the vagaries of religion. She admired people overlooking religious differences for the common good of all. The harsh separation of denominations was clearly illustrated in Kyneton, where in Chisholm's time four solid churches cornered each other in one facing block. She continued purposefully despite disaffection from both her denominations (Peitsch 2006). Again, her attitude to interfaith and ecumenical relations was ahead of her contemporaries and remains a model for us today. Chisholm strove to show that her own faith was part of something that all should hold in common. To this end, she was fond of using expressions like 'God's Providence' and references to 'His fatherly concern'. The cause of emigration was, she felt, in a profound sense, God's work. But, she had never seen it as even remotely connected with the Catholic mission effort. It was simply a practical charitable project, making the blessings of God's providence available to all in need (Hoban 1984).

Chisholm's compassionate consideration is largely discounted in our society while others are venerated. Public adoration is saved for more seemingly 'worthwhile' people. 'Name an Australian hero,' is what I asked of my university's, fourth-year Education students. Apart from the movie stars, sports stars and a bushranger or two, the silence spoke volumes. I then suggested that we did have a hero-not unlike the incredibly important Mother Teresa. In fact, Mother Teresa and our hero, Caroline Chisholm, were both celebrated and known to work for the same power whom Caroline called 'Providence'. My students are unconvinced. 
However, Chisholm was not 'heavenly minded' or only invested in the welfare of European settlers; she also voiced her concern about the treatment of indigenous Australians (Hoban 1974). She was interested in the wellbeing of others and free from many of the prejudices of the time long before it was acceptable: 'Caroline Chisholm's work was always focused on social justice and she had a determination to make things happen. When she lived in Kyneton she would give the local Chinese people English lessons' (Jennison 2005). Chisholm was unilateral in all her social dealings.

\section{The Family Colonisation Scheme}

A significant aspect of Chisholm's contribution to her community was her ability to design and operate workable systems for the good of all concerned. In the words of a living Chisholm (2005) descendant:

'She was quite forceful but in a very pleasant and feminine way. I also think she was intensely practical so when she came to talk to a bureaucrat or Government official they were always amazed first of all how practical she was and secondly as to what she'd already done before she got to their door. So it was hard for them to deny'.

However, Chisholm's initial plans to interest the English government in assisting the passage of free settlers to Australia failed (Iltis 1966). Then '...in 1849 she founded The Family Colonization Society. The society encouraged and helped families to accumulate the cost of half their fare, the remainder to be loaned by the society and to be repaid within two years in Australia' (Walker 2009, p. 83) Private investors, rich London merchants, and philanthropists in England supplied the funds backing this scheme. It was an ambitious project and somewhat risky for all concerned but was the catalyst for successful travel for many families. The loans were generally not repaid in the allotted time due to difficulties within the struggling Australian economy-but that does not diminish the ingenuity and effectiveness of the original plan.

\section{A Continuing Inspiration Today}

Chisholm's life is effective as a catalyst for further creativity today. As a visual artist, art educationist and researcher, I have been privileged to attempt to bring to life her heartfelt actions and significant accomplishments. I see great value in this for the area of public pedagogies which 'draws from an emerging, more programmatic strand of literature which aims at deliberative, active political interventions in society and emphasizes that there is 'educational work' to be done in and for the public sphere' (Schuermans, et al., 2012). The socially progressive act of art-making can facilitate 'repairing social gaps' (Luse, n.d.) As a result, I routinely offer projects for participants across the country.

On one occasion, I used the common household 'apron' as a symbol of Chisholm's being ready in service for others. The catch phrase of the project is 'You are here to make a difference. The future belongs to you' (Mah, 2005). Figuratively speaking, there is an apron with everyone's name on it.

For this project I selected and approached craft people known to me from all over Australia. Their task was to hand work a letter(s) onto a plain Victorian-inspired cotton apron from the exhibition's title Chisholm's Homes, investing ability, creativity, time and energy into an important part of the whole project.

This aspect of the installation combined women's home craft skills with making a statement about valuing everyone's expertise and contribution to their communities. It can also be seen as a decorative tribute to Chisholm who, though living in a resplendent era, took little opportunity to settle into the frivolities of life. 

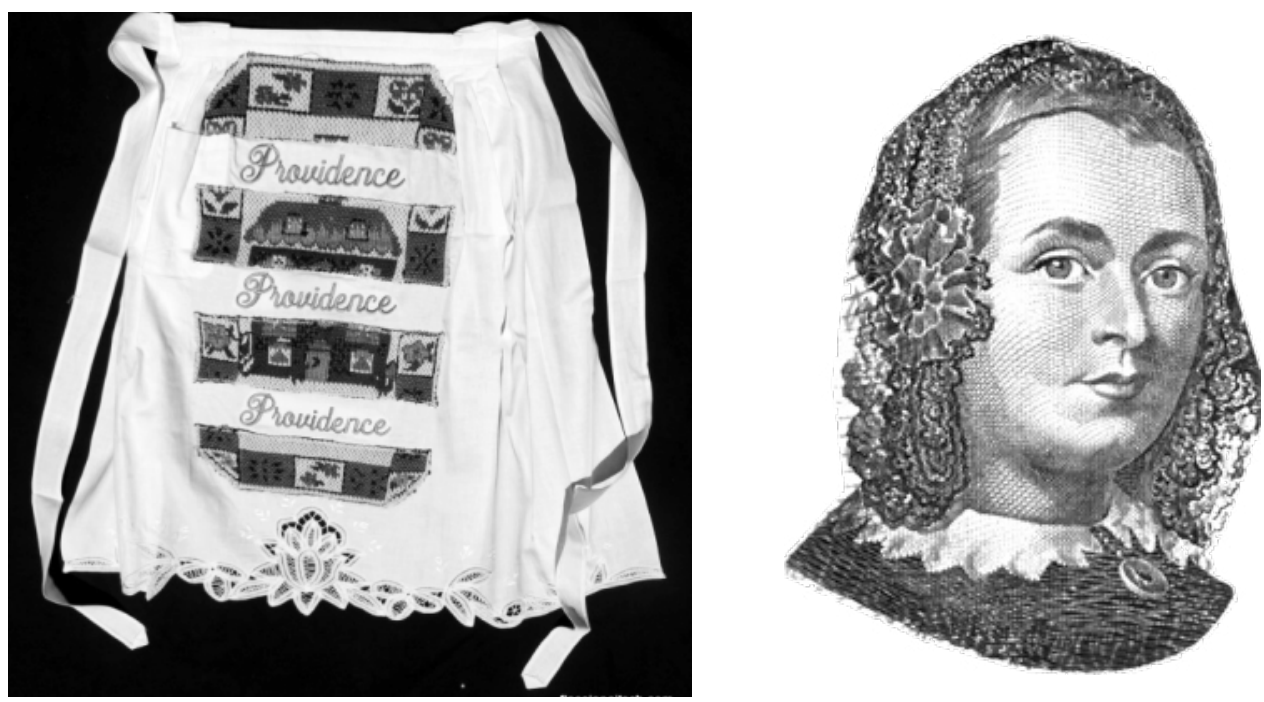

Figure 11: One of fourteen (14) handmade aprons celebrating Chisholm's life (above, left).

Figure 12: Image of Chisholm once used on the Australian five (5) dollar note (above, right).

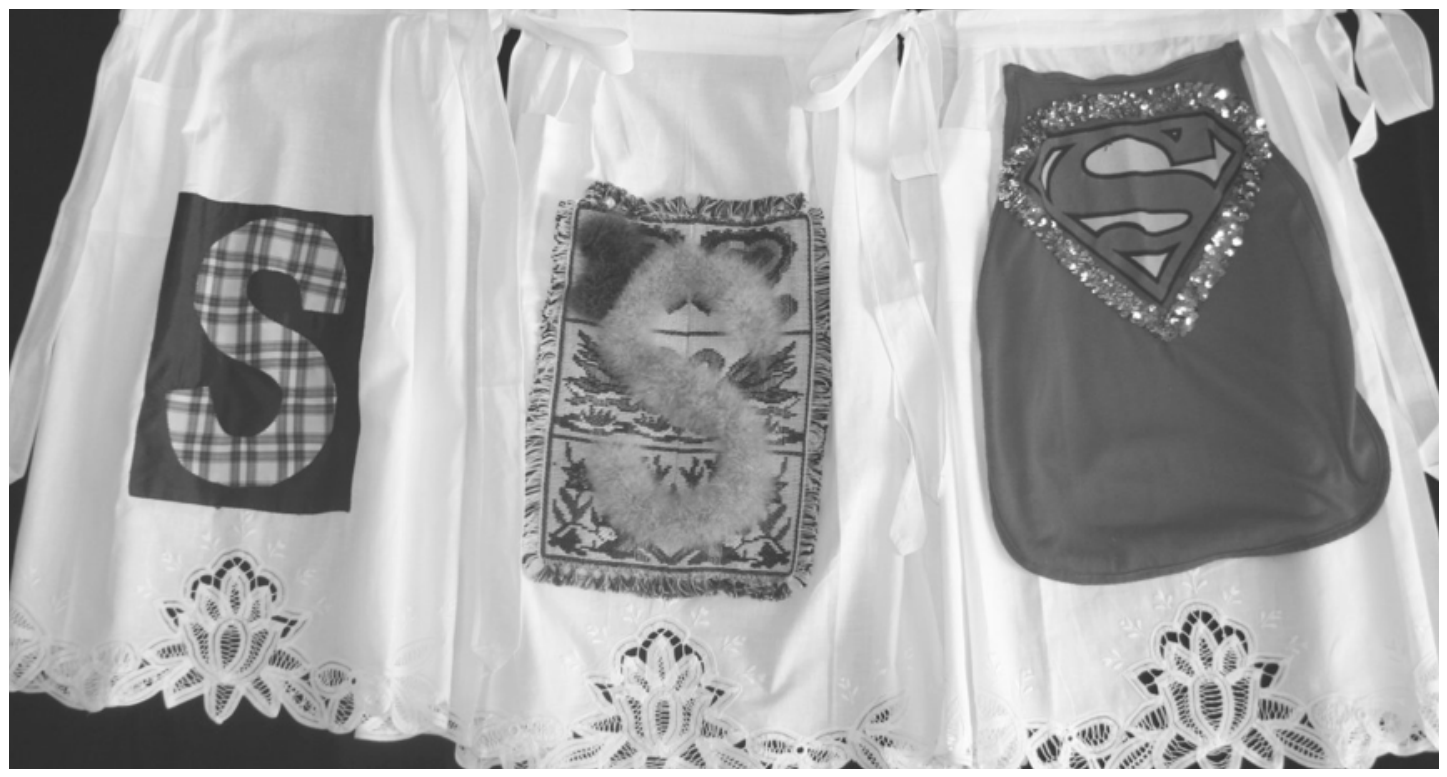

Figure 14: Three (3) aprons for Chisholm's Homes

Examples of 'Apron Stories' below, that accompanied the aprons, highlight the sentiment of this project (Peitsch, 2005):

Left - LETTER S by Marian Lieschke: 'The plaid letter I used I cut from the very first school dress I made for my daughters - worn by all four and now outgrown. Caroline also saw to the education of girls in her time. The glossy blue background is cut from the most expensive material I ever bought but had never successfully made anything from until now.'

Centre - LETTER S by Flossie Peitsch: 'My mother raised geese. She knew them each by name. Touching the sensual downy grey trim so like the curved neck of a gander drew me back to a time that is part of my history and lost homeland. Caroline must have had many such remembrances too.'

Right - LETTER S by Flossie Peitsch: 'My apron allowed me to use a saved, maybe even sacred artifact from my children's' history. It is a superman cape from some favorite worn-out pajamas. It seemed a very suitable symbol for Caroline.' 
Along with the aprons, I have enjoyed many opportunities to exhibit art as a reflection on the life and essence of Caroline Chisholm. Dr Helen Szoke, CEO Victorian Equal Opportunity and Human Rights Commission said in her Opening speech for one such commemorative exhibition at Victoria University, 'Through this exhibition, we have cause to remember and reflect on the role that individuals may play to make a difference' (2008).

\section{Conclusion}

Many of the issues Chisholm signalled have echoes in contemporary society (Hulsbosch, 2008). The role and well-being of women, their responsibility for children, especially when considered in the context of working women, is still a critical issue, particularly in semi-rural areas. Immigration, refugee integration, and multiculturalism continue to be controversial topics in Australia. Women's health and abuse issues, acceptance of religious or sexual preference, housing affordability, are all challenges we face today. Good citizenship and social accountability, though desired, now seem more unattainable than ever.

Ironically, Chisholm has recently been marginalised and stigmatised with the label of anti-feminist for not actively supporting the fight for equal rights, and for placing single women in domestic employment in the areas of Australia where she knew single men would be looking for wives (Walker, 2009). Today, Chisholm is largely overlooked in the remembered official history of Australia. Implausibly, the impressive new Museum of Australia in Canberra has not made the slightest mention of her. While there may be genuine reasons for this, they shouldn't justify exclusion. For those of us rediscovering her history, Chisholm continues to be the 'hero' she was in the tempestuous gold rush days-showing the way ahead and this, way ahead of her time.

'Self in service to others' is a worthwhile summary of Chisholm's life. In 1934, Dewey wrote 'The things in civilization we most prize are not of ourselves. They exist by grace of the doings and sufferings of the continuous human community in which we are a link' (cited in Kridel 2010). I believe this statement is our linkage with the work of Caroline Chisholm. It is also connects with work in the field of public pedagogies that 'celebrates the transformative articulations that express multidisciplinary conceptions of the public while challenging how artistic research and ways of being are pedagogical within the everyday (Charman, 2014).

\section{References}

Bogle, J 1993, Caroline Chisholm: The Emigrant's Friend, Gracewing Books, Leominster.

Charman, K 2014, Public Pedagigies Institute, viewed 12 September 2017, <http://www. publicpedagogies.org/about/>

Chisholm, D 2005, A Great, Great Grandson's Telling [Interview] 2005.

Footscray Community Arts Centre, Arts Learning Forum, viewed 12 September 2017, $<$ http://footscrayarts.com/event/arts-learning-forum/>.

Giroux, H 2004, 'Cultural Studies, Public Pedagogy, and the Responsibility of Intellectuals', Communication and Critical Cultural Studies, vol. 1, no. 1, pp. 59 - 79.

Henry, G 2004, 'Public Pedagogy and the Politics of Neo-liberalism: making the political more pedagogical' Policy Futures in Education, vol. 2, no. 3 \& 4, pp. 494 - 503. 
Hoban, M 1974, Fifty-one pieces of Wedding Cake: A Biography of Caroline Chisholm, Lowden publishing Co., Kilmore.

Hodgkin, K 2016, 'Raphael Samuel History Centre', Public Pedagogies Institute Conference, Footscray, Melbourne.

Holmes, A 2016, Public Pedagogy in Composition Studies, National Council of Teachers of English, Urbana.

Hulsbosch, M 2008, Sleeves \& Sheets, Socks \& Pockets, Wollongong City Gallery, Wollongong.

Iltis, J 1966, 'Caroline Chisholm', Australian Dictionary of Biography, National Centre of Biography, Australian National University, <http://adb.anu.edu.au/biography/ chisholm-caroline-1894>.

Jennison, S 2005, 'A Saint Caroline?', Chisholm's Homes, <http://www.livingmuseum.org. $\mathrm{au} /$ chisholms\%20homes/essays/essay_susanjennison.html>.

Kiddle, M 1950, Caroline Chisholm, Melbourne University Press, Melbourne.

Knights, PS 1992, The Caroline Chisholm Shelter Sheds, Keilor Historical Society, Keilor

Kridel, C 2010, 'Places of Memorialization-Forms of Public Pedagogy', in Handbook of Public Pedagogy: Education and Learning Beyond Schooling, Routledge, New York, pp. 281-285.

Luse, M 2010, The Indypendent, viewed 12 September 2017, <https://indypendent. org/2010/06/essay-a-look-at-art-and-public-pedagogy-in-new-york-city/>

Mah, A 2005, Chinese Cinderella and the Secret Dragon Society, Allen \& Unwin, Crow's Nest, NSW.

Marstin, R 1979, Beyond Our Tribal Gods: The Maturing Faith, Orbis Books, New York.

Murphy, T 2004, Radical in Bonnet and Shawl, Moonee Valley Leader, March 15, 2004

Peitsch, F 2004, Chisholm's Homes, viewed 11 September 2017, <http://exhibitions.flossiePeitsch.com/chisholms_homes/chisholms/index.html>

Peitsch, F 2005, 'Lettered Aprons', Chisholm's Homes, viewed 11 September 2017, <http:// www.livingmuseum.org.au/chisholms\%20homes/community/letteredaprons.html>

Peitsch, F 2006, Art and Soul, Macmillan, Melbourne.

Peitsch, F 2008, The Immortal Now, VDM Verlag, Saarbrucken

Procter, J 2004, Stuart Hall, Routledge Critical Thinkers, Routledge, Abingdon-on-Thames

Sandlin, J, O’Malley, M \& Burdick, J 2001, 'Mapping the Complexity of Public Pedagogy Scholarship: 1894-2010' in Review of Educational Research, no. 81, vol. 3, pp. 338-375.

Schuermans, N, Loopmans, M \& Vandenabeele, J 2012, Public space, public art and public pedagogy, ResearchGate, viewed 12 September 2017, <https:/www.researchgate. net/publication/262870448_Public_space_public_art_and_public_pedagogy> 
Stevens-Chambers, B 2004, Friend and Foe: Caroline Chisholm and the Women of Kyneton 1840 - 2004, Springfield and Hart, Kyneton.

Stevens-Chambers, B 2005, My life and Caroline, viewed 12 September 2017, <http:// www.livingmuseum.org.au/chisholms\%20homes/essays/essay_brendastevensc.html>

Swann, M 1925, Caroline Chaisholm, The Immigrants' Friend, Alfred James Kent, Government Printer, Sydney

Szoke, H 2008, Opening of Chisholm's Homes Exhibition, Victoria University, Melbourne.

Walker, C 2009, A Saviour of Living Cargoes, Australian Scholarly Publishing, North Melbourne

\section{About the Author}

Dr Flossie Peitsch is an academic, and an internationally exhibiting installation, multimedia, performance, and interdisciplinary Visual Artist with a profound focus on kindred spirit Caroline Chisholm. Director of FLO-ART, she resides in Melbourne with interests in social sculpture, generating creative communities through the arts and contemporary spirituality facilitating the self-realization of being. 